\title{
Prediction of Tsunami Hazard Levels Based on GIS Analysis in South Bengkulu Regency
}

\author{
Deded Chandra, Dedi Hermon, Eri Barlian, Indang Dewata, Iswandi Umar
}

\begin{abstract}
This study aimed at a prediction of tsunami hazard levels in South Bengkulu Regency, that is calculated based data on sea-level rise, distance from the coastline, distance from the nearest rivers, and beach slope. Measurement is carried out using Geographic Information System (GIS) analysis with overlay techniques and the methods of scoring/weighting. The results showed in South Bengkulu Regency the tsunami hazard levels of very high class $504.65 \mathrm{Km}$ (44.8\%), high class $160.77 \mathrm{Km}$ (13.7\%), somewhat high class $131.09 \mathrm{Km}(11.2 \%)$, low class $64.92 \mathrm{Km}(5.6$ \%) and very low class $250.39 \mathrm{Km}(21.2 \%)$.
\end{abstract}

Keywords: tsunami, hazard, GIS, South Bengkulu.

\section{INTRODUCTION}

$\mathrm{S}_{\mathrm{o}}$ outh Bengkulu Regency is an area prone to earthquakes and tsunamis. This is because South Bengkulu is close to the meeting of two world tectonic plates, the Indo-Australian Plate and the Eurasian plate [1]. Based on research [2] the plates are active plates, where the Indo-Australian plate moves northward while the Eurasian plates move southward and collide so that they form subduction zones along with the meeting of the two plates. This subduction zone is the main generator of tectonic earthquakes in Bengkulu. A large number of victims due to the disaster is due to the lack of evacuation route designation facilities and the lack of results of counselling prepared for disaster preparedness. The way people respond to evacuation routes is different in every thought. It is this mindset that must be developed and given a path for the creation of public safety.

Based on the above problems, regencies and cities on the coast of Bengkulu Province, including Kaur Regency, South Bengkulu Regency, Seluma Regency, Bengkulu City, Central South Bengkulu Regency, North Bengkulu Regency and Mukomuko Regency. it is feared that it will become the next place that will be hit by a tsunami, therefore efforts are needed to overcome the tsunami hazard. One of the efforts

Revised Manuscript Received on May 15, 2020.

Deded Chandra*, his/her Department of geography and doctoral program of environmental science, Universitas Negeri Padang, Padang, Indonesia. Email: dededchandra@yahoo.com

Dedi Hermon, Department of geography and doctoral program of environmental science, Universitas Negeri Padang, Padang, Indonesia. Email: dihermon006@gmail.com

Eri Barlian, Department of doctoral program of environmental science, Universitas Negeri Padang, Padang, Indonesia. Email: eribarlian@unp.ac.id

Indang Dewata, Department of doctoral program of environmental science, Universitas Negeri Padang, Padang, Indonesia. Email: indangdewata@fmipa.unp.ac.id

Iswandi Umar, Department of geography and doctoral program of environmental science, Universitas Negeri Padang, Padang, Indonesia. Email: iswandi_u@yahoo.com

(c) The Authors. Published by Blue Eyes Intelligence Engineering and Sciences Publication (BEIESP). This is an open access article under the CC BY-NC-ND license (http://creativecommons.org/licenses/by-nc-nd/4.0/)
* Correspondence Author

that can be done is to estimate areas that will be affected by tsunamis based on parameters that affect tsunami hazard, involving analysis of parameters that affect the tsunami hazard level, including sea-level rise, distance from the coastline, distance from the nearest rivers, beach slope, population density, and building density are grouped based on tsunami hazard level variables, [3] so that the results will be presented in the form of a tsunami hazard level map using GIS in South Bengkulu Regency.

This research emphasizes on the level information of tsunami hazard because the tsunami hazard level map is the exact location where the community, the environment or both are potentially exposed to major natural disasters that can cause death, injury, pollution or other damage [4]. The selection of the coast of South Bengkulu Regency as a research location, because this area does not yet have an accurate tsunami hazard map as a reference in determining the regional spatial plan (RTRW).

The use of GIS technology in this research, because it has the advantage of integrating natural, socio-economic, disaster information and also can be an ideal assessment tool to support the tsunami hazard-prone areas planning efforts [5]. This study aims to a prediction of tsunami hazard levels in South Bengkulu Regency using GIS and then identify which areas are at very high classes.

\section{RESEARCH METHODS}

The research area is Bengkulu Selatan Regency. Geographically, it is located west of Bukit Barisan. The administrative area covers 118,610 hectares. Located at $4^{\circ} 9^{\prime} 39^{\prime \prime}-4^{\circ} 33^{\prime} 34^{\prime \prime}$ South Latitude and 102 $47^{\prime} 45^{\prime \prime}$ $-103^{\circ} 17^{\prime} 18^{\prime \prime}$ East Longitude [Fig. 1). Based on the topography, South Bengkulu Regency is located in three lanes, i.e: the first lane (0-100 meters) and classified as lowlands is $50.94 \%$, the second lane (100-1000 meters) is classified as a hilly area reaching $42.99 \%$, and the third lane is located on the North-East to the top of Bukit Barisan, reaching $6.07 \%$. Based on the topography, South Bengkulu Regency has located at an altitude of 0 to 1,000 asl (above sea level). The research method used in this research is a case study. According to [6], case study research is an in-depth study of a case that applies to limited time, place and population, thus providing an overview of the situation and conditions locally and the results cannot be generalized or equated to different places. The method for analyzing the prediction of tsunami hazard in South Bengkulu is using the help of the Spatial Analyst tool with the Cell-Based Modeling method contained in ArcGIS 10.3 Software.

Published By:

Blue Eyes Intelligence Engineering

\& Sciences Publication

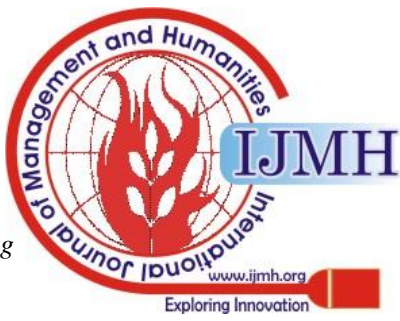


To predict the level of tsunami hazard is done by using overlay techniques on thematic maps such as sea-level rise, distance from the coastline, distance from the nearest rivers, and beach slope. The overlay map is done using the scoring and weighting method.
Each class is multiplied by its weight and added up to produce a hazard value. Next, the hazard value is classified to determine the predicted hazard levels. Data that has been processed are analyzed using descriptive spatial analysis [7-13]. From this analysis describes the spatial distribution of tsunami hazard areas in South Bengkulu Regency.

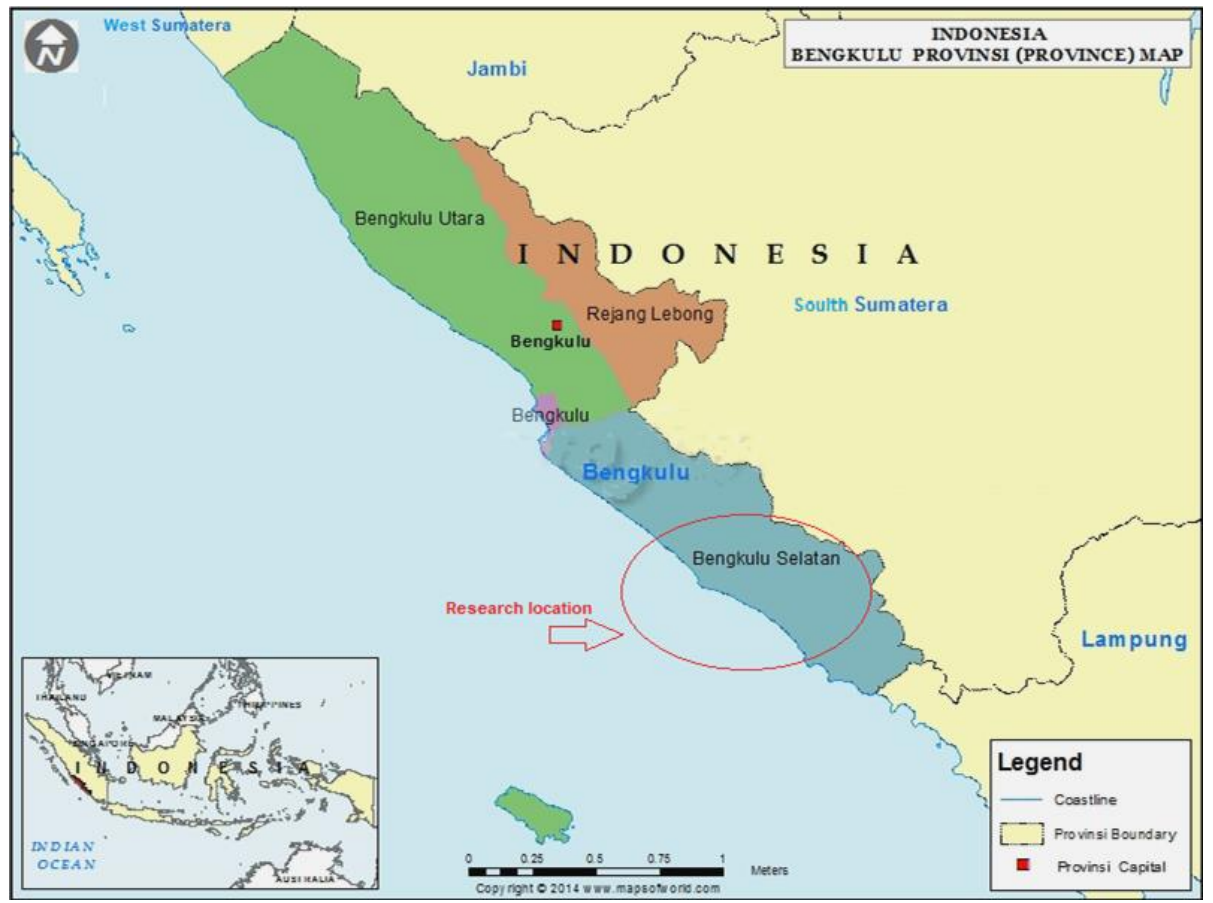

Fig 1. Map of Research Location

\section{RESULTS}

Based on the results of overlay analysis in GIS modelling, the prediction values of tsunami hazard levels in South Bengkulu obtained as much five classes. The extent and percentage of prediction values for tsunami hazard levels can be seen in Table 1.

Table-I: Values and Areas of Tsunami Hazard Levels

\begin{tabular}{|c|l|c|c|}
\hline No & Classification & Area $(\mathrm{Km})$ & Percentage of area (\%) \\
\hline 1 & very high & 504,65 & 44.8 \\
\hline 2 & high & 160.771 & 13.7 \\
\hline 3 & somewhat high & 131.09 & 11.2 \\
\hline 4 & low & 64.92 & 5.6 \\
\hline 5 & very low & 250.39 & 21.2 \\
\hline \multicolumn{2}{|c|}{ Amount } & 1,180 & 100 \\
\hline
\end{tabular}

Spatial prediction analysis of tsunami hazard levels in South Bengkulu Regency is based on factors that influence in determining the level of tsunami hazard. The factors in this study that affect tsunami hazard are sea-level rise, distance from the coastline, distance from the nearest rivers, and beach slope. The plain low in South Bengkulu is near the beach has the highest hazard to the tsunami. This height will affect the tsunami inundation area (Tsunami Inundation Area). Very high tsunami hazard areas in South Bengkulu Regency are found in almost all sub-districts located on the coast in South Bengkulu (Fig.1).

In general, some parts of this low coastal area will be very inundated if a tsunami disaster occurs with the same high run-up. Coastal areas are always a favourite place for settlement. Given the attractiveness of the coastal areas, the coastal community continues to develop along with the development of the settlement, maritime facilities and the construction of a resort. As a result, more and more people and public facilities are threatened by the tsunami. Based on the land use map in South Bengkulu Regency, the majority are in coastal areas.

Empirically, the farther away from the distance from the coastline, the less vulnerable the tsunami is. This is because of the farther away from the distances from the coastline, the smaller the range and run-up of the tsunami. South Bengkulu Regency has a flat to a steep slope. Most of the coastal area in South Bengkulu Regency is flat, this will lead to an increasingly high level of tsunami hazard. On steep beaches, tsunamis will not go too far inland because they are blocked and will be reflected by the beach cliffs. Whereas on the sloping coast, tsunamis can freely strike up to several tens of kilometres inland through rivers.

Based on research [14-17]. the speed of the tsunami depends on the depth of the waters, as a result, the waves accelerate or slow down following the increase or decrease in the depth of the waters, with this process the direction of movement of the waves also changes and the bias wave energy becomes focused or also spreads. In deep waters the tsunami can move at speeds of 500 to 1000 kilometres per hour while in shallow waters the speed slows down to several tens of kilometres per hour, likewise, the height of the tsunami also depends on the depth of the waters. The amplitude of a tsunami that only has a height of one meter in deep waters can rise to tens of meters on the coastline.

Published By:

Blue Eyes Intelligence Engineering

\& Sciences Publication

(C) Copyright: All rights reserved.

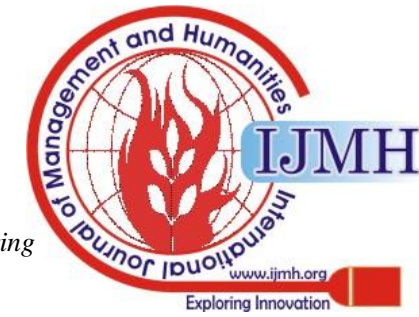


According to $[12,17]$ The history of tsunamis in Indonesia shows that approximately 172 tsunamis occurred in the period between 1600 - 2012. [18] adds the source of the tsunami developt is known that $90 \%$ were caused by tectonic earthquake activity, 9\% due to seabed volcanic activity (example: Krakatoa), and $1 \%$ by sea cliff landslides that occur on the seabed or landslides from land that enters water bodies. Based on the source of the tectonic earthquake there is a potential for a tsunami.

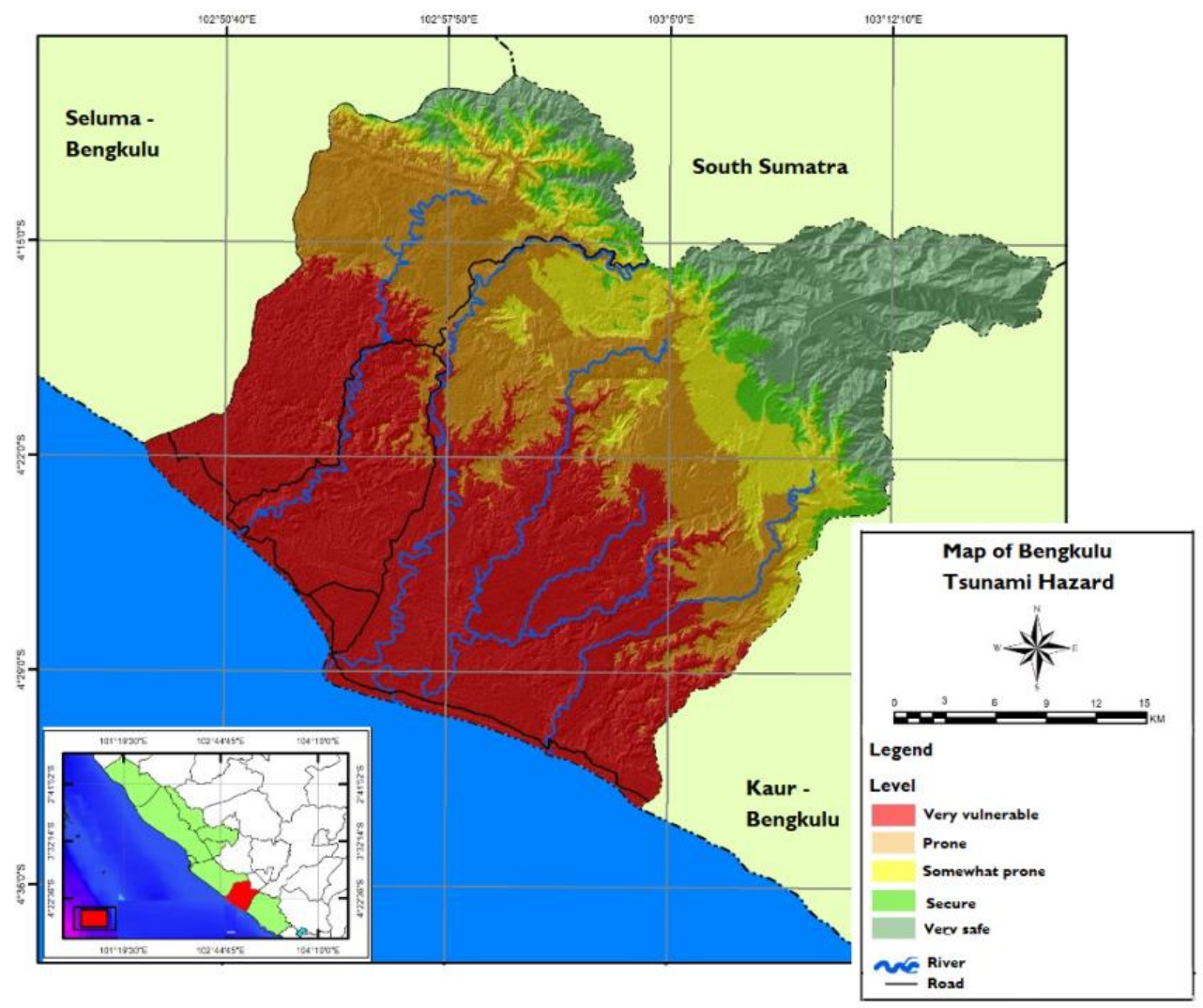

Fig 2. Tsunami Hazard Map of South Bengkulu Regency

\section{CONCLUSION}

Form result analysis the map of the tsunami hazard levels in the coastal area of South Bengkulu Regency, it can be seen the area and percentage of the area in tsunami hazard levels which is covered, very high class $504.65 \mathrm{Km}$ (44.8\%), high class $160.77 \mathrm{Km}$ (13.7\%), somewhat high class $131.09 \mathrm{Km}$ (11.2\%), low class $64.92 \mathrm{Km}$ (5.6 \%) and very low class $250.39 \mathrm{Km}$ (21.2\%). South Bengkulu Regency has a flat to a steep slope. Most of the coastal area in South Bengkulu Regency is flat, this will lead to an increasingly high level of tsunami hazard. On steep beaches, tsunamis will not go too far inland because they are blocked and will be reflected by the beach cliffs. Whereas on the sloping coast, tsunamis can freely strike up to several tens of kilometres inland through rivers.

\section{ACKNOWLEDGEMENT}

This research was supported by Universitas Negeri Padang (UNP). We also thank of Chairman of Postgraduate UNP and Staff, and Students involved in research for their support in this research.

\section{REFERENCES}

1. V.T. Ca and N.D Xuyen, Tsunami risk along the Vietnamese coast. Journal of Water Resources and Environmental Engineering, Vol.. 23, pp.24-33, 2008
2. D.H. Natawidjaja and W. Triyoso, The Sumatran fault zone-From source to hazard. Journal of Earthquake and Tsunami, Vol. 1, Issue. 01, pp. 21-47, 2007

3. D. Pugh and P. Woodworth, Sea-level science: understanding tides, surges, tsunamis and mean sea-level changes. Cambridge University Press, 2014

4. D. Alexander, Natural disasters. Routledge. 2018

5. L. C. Breaker, T. S. Murty, D. Carrol and W. J. Teague, The Response of Monterey Bay to The Great Tohoku, Science Tsunami Hazards, Vol. 30, No. 3, p.153, 2011

6. D. K. Bird, C. Chagué-Goff and A. Gero, Human response to extreme events: A review of three post-tsunami disaster case studies. Australian Geographer, Vol. 42, Issue. 3, pp. 225-239, 2011

7. L. Arlym, D. Hermon, D. Lanin, O. Oktorie and A. Putra. A Policy Model of Preparedness The General Hospital in Reducing Victims of Earthquake and Tsunami Disasters in Siberut Mentawai Island, Indonesia. International Journal of Recent Technology and Engineering (IJRTE). Vol. 8. Issue 3. 2019

8. Arlym, L and D. Hermon. Strategy of Ecotourism Development in Pariaman City. IOP Conference Series: Earth and Environmental Science. Vol. 314. Issue 1. 2019

9. Hermon D. Mitigation and Adaptation DISASTER OF CLIMATE CHANGE. Sara Books Publication. 2019. Gujarat, India. 2019

10. Hermon D. The Strategic Model of Tsunami Based in Coastal Ecotourism Development at Mandeh Regions, West Sumatera Indonesia. Journal of Environment and Earth Science, 6(4), 2016, pp.40-45. 2016

11. Prarikeslan, W., D. Hermon, Y. Suasti and A. Putra. Density, Coverage and Biomass of Seagrass Ecosystem in The Lobam Island, Bintan Regency-Indonesia. IOP Conference Series: Earth and Environmental Science. Vol. 314. Issue 1. 2019

\section{Published By:}

Blue Eyes Intelligence Engineering 
12. Febriandi, D. Lanin, D. Hermon, S. Fatimah, Triyatno and A. Putra. A Dynamics Condition of Coastal Environment in Padang City-Indonesia. IOP Conference Series: Earth and Environmental Science. Vol. 314. Issue 1. 2019

13. D. Hermon, Evaluation of physical development of the coastal tourism regions on tsunami potentially zones in Pariaman City-Indonesia. International Journal of GEOMATE, Vol. 17, Issue. 59, pp.189-196, 2019

14. S. Husrin, W. Kongko and A. Putera, Tsunami Vulnerability of Critical Infrastructures in the City of Padang, West Sumatera. The Proceeding of the 2nd International Conference on Sustainable Infrastructure and Built Environment (SIBE-2013) Bandung

15. A. Putra and H. Mutmainah, The Mapping of Temporary Evacuation Site (TES) and Tsunami Evacuation Route in North Pagai Island, Mentawai Islands Regency-Indonesia. IOP Conference Series: Earth and Environmental Science, 47(1), pp. 012020, 2016

16. S. Husrin, J. Kelvin, A. Putra, J. Prihantono, Y. Cara and A. Hani, Assessment on the characteristics and the damping performance of coastal forests in Pangandaran after the 2006 Java Tsunami. Procedia Earth and Planetary Science, Vol. 12, pp. 20-30, 2013

17. Badan Nasional Penanggulangan Bencana (BNPB), Peraturan Kepala BNPB Nomor 02 Tahun 2012 tentang Pedoman Umum Pengkajian Risiko Bencana. Jakarta, 2012

18. J.C Borrero, K. Sieh, M. Chlieh and C.E. Synolakis, Tsunami inundation modeling for western Sumatra. Proceedings of the National Academy of Sciences, Vol. 103, Issue. 52, pp. 19673-19677, 2006

\section{AUTHORS PROFILE}

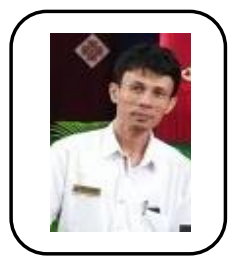

Deded Chandra, is a Research and Lecturer of Geography and Environmental Sciences, Universitas Negeri Padang, obtained the Master Degree in Environmental Science at Universitas Negeri Padang. He is actively involved in any researches regarded to environmental noise, geography physical and produces several scientific works in the form of SINTA-Indonesia indexed journals (ID: 6131579) Right now he is a student Doctoral Program of Environmental Science, Universitas Negeri Padang.

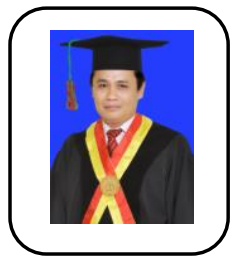

Dedi Hermon, is a Professor of Disaster Geography, obtained the Doctorate Degree in Doctor Program Natural Resources Management and Environment at Bogor Agriculture University, 2009. He is actively involved in any researches regarded to natural disaster, land cover, carbon stock and produces several scientific works in the form of Scopus indexed journals (ID: 57200409691) and scientific books both national and international publications. He is assistant director of Postgraduate Universitas Negeri Padang as well as the head of Study Center of Disaster and Environment, Universitas Negeri Padang.

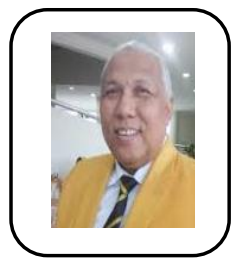

Eri Barlian, is a Professor of Environmental Education, obtained the Doctorate Degree in Doctor Program Education Science at Universitas Negeri Jakarta, 1999. He is actively involved in any researches regarded to environmental education, sports, recreation and disaster and produces several scientific works in the form of Scopus indexed journals (ID: 57202293479). He is Chair of Doctoral Program of Environmental Science, Universitas Negeri Padang.

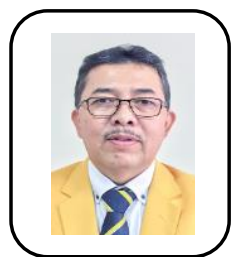

Indang Dewata, is an Associate professor of Environmental Science, obtained the Doctorate Degree in Doctor Program Education Science at Universitas Indonesia, 2009. He is actively involved in any researches regarded to environmental science, chemical and produces several scientific works in the form of Scopus indexed journals (ID: 57202287960). He is Chair of Masters Program of Environmental Science, Universitas Negeri Padang.

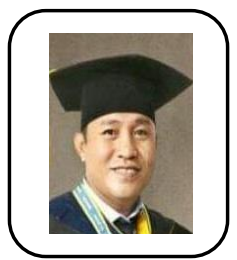

Iswandi Umar, is an Associate professor of Environmental Science, obtained the Doctorate Degree in Doctor Program Natural Resources Management and Environment at Bogor Agriculture University, 2015. He is actively involved in any researches regarded to environmental science, geography and produces several scientific works in the form of Scopus indexed journals (ID: 57204825796). He is Chair of Masters Program of Geography Education, Universitas Negeri Padang

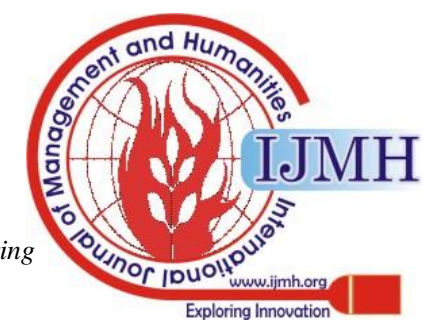

